\title{
Training and Supervision as Predictors of Business Teachers' Job Performance for Policy and Practice in Nigerian Secondary Schools
}

\author{
Tijani, Abdulganiyu Adebayo ${ }^{1 *}$, Etejere, Patricia Agnes $\mathrm{O}^{1}$ \\ ${ }^{1}$ Department of Educational Management, Faculty of Education, University of Ilorin
}

\begin{abstract}
This study investigated training and supervision as predictors of Business Teachers' Job Performance in Nigerian Public Secondary Schools. A Descriptive research design of correlation types was adopted for the study. The population consisted of the entire 1,500 Business related subject teachers from four states in the North Central Geo-Political Zone of Nigeria. 550 samples were purposely selected as the respondents from 20 schools using proportional sampling techniques. A Structured questionnaire was purposely used to collect relevant data from the respondents. However, the checklist was used to collect WAEC/SSCE results of the sampled schools. The validity of the instrument was done by three experts from the Department of Business Education, Kwara State University. The reliability coefficient of 0.71 was obtained through a split-half method. The two research questions stated were answered using percentages and cumulative frequency statistical method, while the three hypotheses generated were tested using multiple regression analysis. The finding of the study revealed the poor performance of a student in Business-related subjects. However, there was a moderate level of Business Teacher job performance. Also, both training and supervision were discovered to be the predictors of Business Teacher Job Performance in Nigeria Public Secondary Schools. Regular capacity building such as workshops and conferences were recommended for the Teachers in addition to the regular external and internal supervision. The Government should also supply the necessary teaching facilities to help the teachers improve on teaching and learning.
\end{abstract}

Keywords: Supervision, School effectiveness, Training, Teacher's job performance.

\section{Introduction}

Training is as old as man himself. At the primitive state of man, the early men were involved in one form of training or the others. They were trained in the use of available implements or tools of farming and hunting as well as in the use of weapons of war.

Those that had to experience were found to be more effective and productive. With the advancement in science and technology, the new era of knowledge, and students' explosion, the need for training and supervision has become imperative. The need for training and supervision for teacher's job performance for school effectiveness cannot be over- emphasized. In Nigeria, even with the introduction of the 6-3-3-4 education system, government spent a huge amount of money on equipment without corresponding training of manpower in terms of teachers to use the machines. That explains the reason why the 63-3-4 system of education has not worked out. The importance of training cannot be overlooked in any organization, be it private or public. The Training of employees plays a great role in the effectiveness of the organization. The training of any employee is of paramount importance and cannot be underestimated in the development and effectiveness of any organization. 
Therefore, many teachers and school managers have nothing to offer in terms of new ideals, facts, theories, and findings in education. On the other hand, the need for effective school supervision in today's education industry cannot be questioned. This is because of the ineffectiveness of many of the schools today. Already, there is evidence of confusion and inefficiencies plaguing the type of educational system we have, thus resulting from poor monitoring systems and lack of adequate supervision and supervisors, in other to achieve efficiency in the nation's educational goals and effectiveness in our school system.

Supervision is concerned with the total teaching and learning process. It is in this regard that the paper describes Supervision as the practice and monitoring of the performance of teaching staff in the school system for further improvement on their curricular activities as a means of enhancing educational goals [1].

\section{Concept of Training}

Training could be described as the process through which employees acquire knowledge, skills, and attitudes that will improve their competencies to enhance their productivity. This study sees training as a procedure through which employees of a particular establishment learn knowledge or skill for the attainment of the set objectives [2]. To this end, training is a tool used by an employee for their accomplishment of the set objectives.

The author sees training as a program designed to improve performance and to bring about measurable changes in the knowledge, skills, attitude, and social behaviour of employees for a particular job [3].

Teachers must therefore be subjected to regular training to enhance teaching and learning. The researcher defines training as a professional development activity engaged in by school personnel to enhance the overall school effectiveness. According to the author, training must not only be concerned with the abilities of individuals currently occupying positions but also with the abilities he will need to qualify for promotion of more responsibilities [4].

The following were the conditions identified by the writer that will serve as a pointer to the need for training. The conditions or symptoms are:

1. Discovery of the training need.

2. Getting ready for the job.

3. Establishing the objectives of the training programme.

4. Identification of training method.

5. Readiness of the employee to undergo training.

6. Excessive Complaints.

7. In subordination and so on; [5]

An Employee should not only be willing to undergo training, but they must also be ready and capable of contributing immensely to the development of the organization's goals [6].

Staff development that also referred to as inservice training, on-the-job training, or professional development, is important in the sense that it helps to mold better teachers and administrators through the improvement of their knowledge and skills. It instills the desire to perform better on their jobs and improves teachers' effectiveness in the classroom or in the office.

Training has no end; it begins as soon as a staff member assumes duty and ends when he retires from active service [7]. It is essential that a very educator has the opportunity to undergo such training within the duration of his appointment. The training must be meaningful and purposeful, and it must also be tailored to meet the needs of the participants. It is ideal for the personnel department to first identify and assess the areas where the staff would need development and training. The need for staff development and training in the school system cannot be overemphasized. This is because we live in a changing world where people's beliefs, values, behaviour, and attitudes change accordingly, and they need to be able to cope 
with the changing circumstances in executing their duties.

Corroborating this, the author asserted that training is an organized activity aimed at imparting information and instructions to improve the recipient's performance in order to help them attain a required level of knowledge and skills [8]. The study expressed that the importance of training and experience cannot be overlooked in any organization, be it private or public [6]. The Training of employees plays a great role in the effectiveness of the organization. Training will no doubt expose the trainer or a worker to new discovery and method that is relevant to the development of the organization. Therefore, many teachers and administrators have nothing to offer in terms of new ideas, facts, theories, and findings in education.

\section{The Concept of Supervision}

Supervision is concerned with the enhancement of the school's effectiveness. It includes the overall development of the curriculum and supply of materials. Another scholar describes it as a process of advising, stimulating, guiding, encouraging, and overseeing workers with the hope of seeking their co-operation in order for the supervisors to be successful in their task of supervision [7].

Supervision of instruction is seen as the practice of monitoring the performance of school staff for further improvement on their job, thereby increasing the standard of schools and achieving educational goals. The paper points out that supervision is an interaction between two or more persons for the improvement of an organization. It is also the process of stimulating growth and as means of helping teachers in their job performance. It has also been described as a process of stimulating growth and a means of helping the teacher to help them [9].

The prominence accorded educational supervision in Nigeria Educational policy tends to reflect the important of supervision in the education enterprise. The primary aim of supervision of instruction is to recognize the inherent worth of each individual and to ensure that the full potentials of all are realized [10]. This is the philosophy underlying the supervision of instruction. The expert describes supervision as the process which aims at helping professional growth and cooperation thereby making teachers become self-directive, creative, and more productive. According to this author, the ultimate purpose of supervision of instruction is the improvement of people learning processes [11].

Supervision was seen as a supporting service to teachers in that it helps them to understand their problems and assist them to seek the best methods of solving them [7]. Again, the concept was assessed to be a problem-solving approach that helps to enhance teachers' performance and promotes a conductive climate for effective teaching and learning [1].

\section{Teachers Job Performance}

The difficulty of determining the effectiveness or performance of teachers has been expressed by many writers. Therefore, to ascertain the competence of teachers or administrators is a very difficult matter, establishing criteria for competence is essentially a variable procedure and vary from district to district [14]. Perhaps trying to offer an explanation for the teacher, The stimuli which infringe upon the pupils are various and difficult to measure which could not explain the dynamic nature of pupil's behaviour as a result of teachers' influence on them [12]. The Ability to perform the task is an obvious variable. However, they said, to the extent that people are put in jobs which demands skills and abilities that they either do not possess or have below the required, lower than desired levels of job performance should be expected [13]. The above authors observed further that the amount of motivation is the second determinant of job performance, this, in turn, is a function of the strength of the need for achievement, believe 
that one is being well paid, the job requires skills and abilities values by the employees, which they believe they possess, feedback is given, opportunity to participate, performance instrumental to promotion, salary increase, coworker acceptability and so on.

\section{School Effectiveness.}

Teacher job performance was described as a variable that has a positive impact on the school ineffectiveness [7]. Speaking on a wider scope, effectiveness is the degree to which an organization strives to achieve its goals. For example, if schools A and B have one goal that the reading ages of all pupils should not be lower than their chronological ages and both achieved this goal, it means both schools are equally effective. But if school A had achieved this goal with the number of teachers and half the amount of reading materials than school B, it means that school $\mathrm{A}$ is more effective. In this case, effectiveness would then be a reasonably straight forward concept the concept of organizational goal was equally clear. $\mathrm{He}$ further stated that effectiveness defines the interdependent relationship between purpose, effort, and accomplishment. It translates judgements, ratings, and accomplishments. The combination of all these three variables made it possible to compare achievement to aims, or put in another way, to assess performance against objectives. Consequently, an active school must be able to compete favorably in terms of output and reputation within Its comparable cohort of schools, an organization is made up of any group of people who have united together to pursue and accomplish a common goal as one team. Every organization needs to work towards effectiveness in the realization of its goals. Effectiveness is the extent to which an organization realizes its goals or objectives. This is the attainment of the specific desired ends in an organization. There are three elements in the administrative effectiveness on the part of the principal. They are vision, initiative, and resourcefulness. They condition the manner and style of behaviour of principals. Three factors were identified as criteria for performance, and these are student's examination results, absenteeism, and turnover [14]. In summary, effectiveness can be termed as a measure of organizational performance. It involves doing the right things, producing creative alternatives, optimizing resources utilization, obtaining, and increasing results. Among the determinants of effectiveness are productivity, stability, high morale, low turnover rate, maximization of individual potentials, values contributed to the society, and satisfaction of employee needs.

\section{The Predicament of the Nigeria Public Education System}

The quality of school products has been a great concern to stakeholders in the educational sector and the public in general. There is the need to bring back the glory of education. To do this, there is the need to embark on training, staff development as well as thorough supervision. "The overall effects of having accidental teachers are all evident around us: poor students and ever declining quality of education. The WAEC results of year 2015 in Business subjects showed that things are getting worse in the nation's education sector. We talk about large percentage of failure among students, but it is instructive to consider the quality of those who teach them in the first place" [14].

For example, if a person who graduated with a low grade is employed as a teacher, then we should expect that he would also produce students who are no better in the attainment of good grades. Training and supervision are the major prerequisite to enhance his job performance. The Federal Government seems to have lost focus as far as concentrating on planning, policy formulation, and maintenance of these standards. Supervision of schools has been neglected by all tiers of government, leading to poor quality of teaching, and learning Schools are poorly funded, teachers are poorly 
remunerated, and classes are overcrowded. The schools have no teaching aids, and the quality of teachers is poor [14].

The Federal Government must accord education its priority through the formulation of sound policies, proper funding, and strict enforcement of the various laws of education if our education and the school system is going to be effective. The state government must be carried along in all this. A nation that neglects the education of its people will remain at the backwater of the new knowledge-driven global order. It was of the opinion that performance is a result of input and that performance measures are rating used to evaluate employees [8]. The author stated that "the only true measure of an individual's effectiveness on the job is his or her value to the organization and this is through job performance". Teacher's job performance implies that there is a maximized qualitative and quantitative performance, which fosters and is measured through student's maximized performance or output on the part of the teacher using all available resources within his reach and geared towards the attainment of goals and objectives in a school system.

The teachers are the initiators and facilitators of teaching and learning activities, and they act as agents in higher institutions, and because of these roles they perform, they can be regarded as the heart of quality improvement strategy [15].

\section{The Problem}

With the advancement in science and technology and the new era of knowledge explosion, the need for training becomes essential. The major identified problem that warranted this study is that there are few trained and competent teachers in the Nigeria school system [14]. Also, supervision of schools has been neglected by all tiers of government, leading to poor quality of teaching and learning. The schools have no teaching aids, and the quality of teachers is poor. This paper, therefore, examines the impact of training and supervision on teacher's job performance in Nigeria Secondary Schools.

\section{Study Objective}

This study examined the relationship among training, supervision, and teachers' job performance in business-related subjects in the Nigeria school system. This is determined through the investigation of the relationship that exists between independent and dependent variables of the study. Specifically, the study carried out an examination of the relationship between the training and business teacher job performance and to determine which of the two independent variables contribute significantly to the job performance of business teachers. Also, the study examines the level of business teacher job performance in the Nigerian School System.

\section{Research Questions}

1. What is the level of Business Teacher Job Performance in Nigeria Secondary Schools?

2. What are the overviews of the students' Academic performance in Business related subjects between 2015-2019?

\section{Research Hypotheses}

H1: There is no significant relationship among training, supervision, and Business Teacher Job Performance in Nigeria Secondary Schools.

$\mathrm{H} 2$ : There is no significant relationship between Training and Business Teacher Job Performance.

H3: There is no significant relationship between supervision and Business Teachers' Job Performance.

\section{Methodology}

This study adopts a descriptive research design of correlational types. It examines the relationship that exists among Training, Supervision, and Teachers' Job Performance in Nigeria Public Secondary School. This design was considered answered appropriate because it 
collects relevant data on the variables of the study and correlates the dependent variables (Training and Supervision) against the independent variable (Teacher job performance).

The population for the study consisted of 1,500 Business related subjects Teachers from the North Central Geo-Political zone of secondary schools in Nigeria. The respondents were selected through purposive sampling techniques of multi-stage procedure.

The data for the study were collected through a well-structured questionnaire. This instrument was validated by three experts from the Department of Business Education, Kwara State University, Malete. The reliability test was conducted through a split-half method, and a regression coefficient of $71.6 \%$ was obtained, which justified the reliability of the instrument.
The research questions stated were answered through percentages and cumulative frequency method, while the multiple regression analysis was used to test all the hypotheses generated for the study.

The result indicated average level of students' performance in Business-related subjects. There was also a moderate level of Teacher Job Performance over the five years under-study. The finding also discovered a significant relationship among training, supervision, and Business Teachers' Job Performance. The dependent variables were also found to be significantly related to the teacher job performance.

\section{Results and Discussion of Findings}

Question 1: What is the level of Business Teacher Job Performance in Nigeria Public Secondary Schools?

Table 1. Level of Business Teachers Job Performance in Public Secondary Schools.

\begin{tabular}{|l|l|l|l|}
\hline Variable & Response & Percentages (\%) & Cumulative \\
\hline Low & 30 & 5.4 & 30 \\
\hline Moderate & 380 & 66.5 & 410 \\
\hline High & 145 & 26.1 & 555 \\
\hline Total & 555 & 100 & - \\
\hline
\end{tabular}

Table 1 Shows that majority of respondents (380) representing $66.5 \%$ rated the level of Business Teachers moderate in the selected public secondary schools in Nigeria. This rating might be unconnected with inadequate Teacher Training on one hand and irregular supervision However, Teachers still show a significant importance to their co-curricular activities and responsibilities to their colleagues and students.

Research Question 2: What are the overall performances of Business-related subjects between the 2015-2019 Academic Sessions? on the other-hard.

Table 2. Level of Student Performance of Business-related Subjects in Economics, Commerce, and Financial Accounting in the Selected Nigeria Public Secondary Schools with 5 Credits and above in WAEC/SSCE

\begin{tabular}{|l|l|l|}
\hline Year & No. of Students Enrolled & \% Passed with credit \\
\hline 2015 & 4,202 & 45.08 \\
\hline 2016 & 4,504 & 49.22 \\
\hline 2017 & 4,029 & 54.05 \\
\hline 2018 & 5,076 & 61.21 \\
\hline 2019 & 4,755 & 38.76 \\
\hline
\end{tabular}


Table 2 indicates the total number of students that enrolled for Business-related subjects in Economics, Commerce, and Financial Account combined in Kwara, Niger, Sokoto, and Benue States, Nigeria. It only takes congnisant of the number passed with credit level in West Africa Examination Council in Senior School Certificate Examination between 2015-2019. It could be observed that it is only in the years 2017 and 2018 that most of the students passed above average with credit level. This level of passes could be attributed to the level of Teachers/ Training and Supervision in those years.
In the contrary, it was recognised that staff development programs such as seminars, workshops, conferences, on-the job training, and off-job training as conditions for ensuring a high level of teachers' job performance and hence students' academic performance in secondary schools [16].

\section{Research Hypotheses}

H1: There is no significant relationship among Training, Supervision and Business Teachers' Job Performance.

Table 3. Regression Analysis of the Relationship among Training, Supervision and Job Performance of Business Teachers

\begin{tabular}{|l|l|l|l|}
\hline Variable & Training & Supervision & $\begin{array}{l}\text { Job } \\
\text { Performance }\end{array}$ \\
\hline Training & 1,000 & .684 & .786 \\
\hline Supervision & .684 & 1000 & .089 \\
\hline Job Performance & 786 & 089 & 1,000 \\
\hline
\end{tabular}

Table 3 shows that the regression coefficient of the relationship between training of and teacher job performance was .786 , while the coefficient of the relationship between supervision of Teachers and their job performance was .089. Also, the coefficient of the relationship between training and supervision of teachers was .684. This result indicated a significant relationship among training supervision and teacher job performance in Nigerian Public Secondary Schools. However, when the variables are treated in isolation, a high and positive correlation are noted for both training of teachers and their supervision on the one hand with a regression coefficient of .684 and training of teacher and their job performance on the other with a regression coefficient of .786 . The regression coefficient of supervision of teachers and their job performance is .089 , which is less than $1 \%$ and was apparently very low. This could not contribute much to the relationship between dependent and independent variables.
The finding explained that the rate at which teachers perform in their job depends majorly on the amount of teacher training and supervision in the school system and which may, in turn to a large extent, determine the student's academic performance in Nigerian public secondary schools.

Training of teachers may not in isolation bring about their job performance in secondary schools, but a combination of other factors such as supervision and quality of teachers is not noticed to exercise much significant impact on teacher jobs performance.

In the contrary, however, another author commented that organisation training and teacher's commitment to duty contributes positively to student's academic performance. [17] On the other hand, it was noted that teachers' attitude to work and motivation have a long role to play at enhancing their job performance. [18]. 
Table 4. Significant Test of Regression weight of each the Independent Variable and Business Teacher Job Performance

\begin{tabular}{|l|l|l|l|l|l|}
\hline Variable & B & Standard Error & Beta & T-value & R2 \\
\hline Constant & 312.31 & 5.88 & .31 & 18.91 & 0.52 \\
\hline Training & 40734.21 & 0.08 & .41 & 52.13 & \\
\hline Supervision & 30734. & 0.21 & .32 & 38.32 & \\
\hline
\end{tabular}

Table 4 shows that using training and supervision as predictors of Business Teachers Job Performance for Policy and Practice in Nigerians Secondary Schools, a regression weight (beta) of .41 and .32 were respectively obtained. These standardized regression values were significant with a $52 \%$ confidence level for the prediction of teacher job performance.

However, it indicates that the training of teachers has a higher contribution of $41 \%$ in the prediction of the dependent variable. The analysis shows a strong indication that the Rsquare (R2) of .52 is significant enough to reject the null hypothesis. Hence, the null hypothesis, which states that there is no significant relationship among training, supervision of teachers, and their job performance, is rejected. The result can be explained in the context that a better teacher job performance in secondary schools could be attained if the required qualified teachers supplied are trained and efficiently supervised. Manpower development is noted as the major determinant of workers' job performance [19]. The result in Table 1 revealed a moderate level of teachers' job performance in business-related subjects in Nigerian secondary schools. This finding was tally with the authors' observation that the poor level of student's academic performance in the West African Examination Council (WAEC) in Kwara state was due to the low level of secondary school teachers' job performance [14].

In contrary, another author attributed a low level of student academic performance in secondary school to poor teachers' instructional supervision by the principal at this level of an educational system [20]. Result in Table 2 attributed poor level of students' Academic
Performance to the inadequate level of teacher training and supervision. This thus signified a positive correlation between teacher training and supervision on one hand and students' Academic performance on the other. This result is in line with the finding by the author, who observed that teacher training is a correlate of teacher productivity in secondary schools of Ojo Local Government Area of Lagos State, Nigeria [3].

The relationship among training, supervision and teacher-job performance was showcased in Table 3 and 4 . The training was considered as an improvement in the knowledge and skill of teachers in their present job while monitoring the performance of teachers for the improvement of the curricular and co-curricular of the school activities.

Training is thus a teacher professional development activity that could enhance their knowledge, skills, and attitudes in the conduct of teaching and learning. This corroborates the findings of the writers who jointly observed a significant impact of training on the digitalization of education for the effectiveness of the school system [15]. Supervision could be seen as a quality assurance mechanism of a teacher-directed to the attainment of educational goals and objectives. [11] stated that the school head is the supervisor of the instruction in the school system. This thus implied that the school principal is shaded with the responsibility of improving pupil-learning outcomes and attainment of educational objectives through supervision [10]. The following could be identified as some notable roles of the school head.

1. Ensuring that every personnel do what he or she is employed to do. 
2. Ensure a smooth flow of educational activities.

3. Paying a regular visit to the classroom to observe lessons.

4. Ensure adequate provision of instructional materials.

5. Maintain discipline among staff and students.

\section{Implications for Policy and Practice of Secondary School Education}

Policy maker should know that both training and supervision are inevitable tools for enhancing the effectiveness of secondary schools in Nigeria. It is pertinent to note that training as a form of capacity building is aimed at enhancing teachers' job performance as it improves the knowledge, skills, and capability of a teacher to perform the teaching task efficiently. Training is an inevitable tool that can be used in school to broaden the knowledge of teachers. It also helps to acquire the needed skills and attitudes that help teachers to perform effectively in the classroom. The goal of training is to create an impact that will last beyond the end time of the training itself. The focus is on creating specific action and commitment that enable workers to incorporate their new skills and idea back at work.

Furthermore, school supervision assists the school policy maker such as the State Ministry of Education and Teaching service Commission to gather necessary information about the school's concerning teachers, students, and other related issues in their decision-making.

School supervision is also necessary as it guides the head teachers towards proper administration of the school and ensures that everyone is in the school community work as a team towards the attainment of the educational objectives. Finally, school supervision ensures that public funds are judiciously spent and properly accounted for, as it calls for special investigation on fraud, the act of indiscipline, and any other problem confronting the secondary school system in Nigeria.

\section{Conclusion}

This paper concludes that Teacher training is a vital tool to their job performance. If teachers are well trained, they will perform better in classroom teaching and learning. Thus, training enhances quality teaching that will promote thus improve of student academic performance in Nigeria Secondary schools. Similarly, if the government supplies qualified teachers to schools and such teachers are well supervised, the goal of the school will be attained as well as school effectiveness.

In as much as the school system needs supervision to achieve the desired educational objective, it's therefore happening to be a good mechanism to upgrade teachers into a required standard. Teachers need supervision to work harder no matter their level of experience devotions. Without supervision, both teachers and school administrators backslide rapidly in their job performance and hence the schools' effectiveness. School supervision helps to enhance teaching and learning effectiveness through the improvement of teachers' professional competence, which includes both technical skills and the pedagogical skills of teachers that are capable of facilitating student learning as well as his reflective skills. This is made possible when teachers are adequately trained and effectively supervised.

\section{Recommendations}

Among recommendations made are or effective teaching and learning.

1. Adequate training such as workshop, conference and in-service training should be regularly made available to the education teacher for improvement.

2. Regular supervision (both internal and external) should be conducted the school heads and Ministry of Education.

3. The necessary Training facilities for the Teaching of Business subjects should be made available in sufficient quantities for effective teaching and learning in Nigeria Secondary Schools. 


\section{Acknowledgement}

This is to acknowledge and appreciate all the authors cited in this manuscript. Your works are indeed very useful for the completion of this research. You all referenced. I equally appreciate my research partner and assistance.

\section{References}

[1] Tijani, A. A. (2016). planning and supervision in education. Second revised edition. Ilorin; Ola Press.

[2] Dale, E. (1980). Management theory and practice Fourth Ed. Auckland McGraw Hill.

[3] Biswajeet P. (2012). Human Resources Management. Portharcout; learning private Limited.

[4] Ahiaba, K.P (2002). Training and experience as a correlate of teacher's productivity Secondary Ojo Local Education District of Lagos State A PGDE project Ajasin University, Akungba, Ondo State, Nigeria.

[5] Nwachukwu, C.C. (1988). Management: Theory and practice. Onitsha: African PCP publishers Limited.

[6] Adeogun, A.A (2006). Training and experience as predictors of teacher's productivity in secondary schools in Nigeria International Journal of Educational Management. 6(2).12-21. Indemac (Nigeria publishers) Limited.

[7] Ogunaju, S (2006) The craft of Educational Management, Ilorin. Indemac Print Media, 153-167.

[8] Alabi, A.T. (2000), School personnel Management. In Durasaro, F. The craft of educational management. Ilorin, Hayette press.

[9] Adepoju, T.L (1993) Fundamental of school administration planning and supervision in Nigeria. Ibadan, Alafasy.

[10]Aina, O. I. (2012) Personnel management in Nigeria central approach. Ikeja.

[11] IJaiya, NYS (1991). A Guide to supervision of Instruction ilorin: My Grace Graphics Repro. Co.

[12]Edem, D. A (2012). Introduction to Educational Administration in Nigeria. New Delhi: Thomas Press Ltd.

[13] Margerison, C. \& McCain, D. (2004) High performing Managerial Teams, Leadership
The efforts of family, friends, typist and even the publisher are acknowledged.

\section{Conflict of Interest}

The author declares that there is no conflict of interest.

\&Organization Development Journal. In psychological Abstracts.

[14] Tijani, A.A (2013). Utilization of Teachers for school effectiveness in Kwara State Public Secondary Schools. International Journal of Educational Management. 11(1): 61-70 Published by the Department of Educational Management, University of Ilorin, Nigeria.

[15] Abdullahi, N.J.K \& Tijani, A.A (2019). Digitalization in Education System and Management of early childhood education in Nigeria. Southeast Asia Early Childhood Journal (SAECJ). 8(2).20-42. Published by Pendikan Sultan Idris University, Malaysia.

[16] Oyedeji, M.B (2012). Management in education: Principle and practice. Ilorin: Success Educational Services.

[17] Cagri, B. \& Osman, C. (2010). The effect of organisational training on organisational commitment. International Journal of training and Development, 14 (4); 309-322.

[18] Mohammed, L. Mashi. M.S \& Salisu, M. (2017). Job attitude and employee performance; an empirical study of non-academic staff of Bauchi State University, Nigeria. International Journal of Business and Management. 1 (1); 1-13.

[19] Onuka, A.O.U \& Ajayi, K.O. (2012). Effects of manpower development on workers' job performance. European Journal of Education studies. 4(3); 423-433.

[20] Onoguere, E. O, Nyorere, A, O \& Muraina, M.B (2015). In service training: A panacea for improving the quality of teaching at the pre-basic and basic education levels. Studies in Education, 14 (1), 23-34. 